\title{
ANALISIS POLA MAKAN PADA ANAK USIA SEKOLAH
}

\author{
Afriyani Rahmawati ${ }^{1 *}$, Carolina Wurisetyaningrum Marland ${ }^{1}$, Eka Putri Wahyuni ${ }^{1}$, \\ Husnul Aliffa Zulkarnaen ${ }^{1}$, Meissy Okasari ${ }^{1}$, Nasyafia Febri Alfani ${ }^{1}$, Rizky Lusiana ${ }^{1}$ \\ ${ }^{1}$ Program Studi Pendidikan Kesejahteraan Keluarga, Fakultas Teknik, Universitas Negeri Jakarta, \\ Jakarta Timur 13220, Indonesia \\ *)E-mail: afibintang@gmail.com
}

\begin{abstract}
Abstrak
Makanan yang dikonsumsi oleh anak usia sekolah sangat mempengaruhi perkembangan fisik. Orang tua memiliki peran untuk melakukan pengontrolan dan pengawasan terkait dengan pola makan anak karena anak usia sekolah rentan terkena penyakit terutama permasalahan gizi. Tujuan penelitian ini untuk mendeskripsikan dan menganalisis pola makan pada anak usia sekolah. Penelitian ini dilakukan pada bulan Desember 2019. Penelitian ini melibatkan 97 orang siswa di SDN Sumur Batu 01 Pagi Kemayoran, Jakarta yang dipilih dengan teknik stratified sampling. Pola makan diukur dengan menggunakan instrument The feeding practices and structure quistionnare (FPSQ) (Jansen, Mallan, Nicholson, \& Daniels, 2014). Pola makan anak dilihat berdasarkan 8 dimensi, yaitu: dimensi ketidakpercayaan nafsu makan, hadiah untuk perilaku, hadiah untuk makan, makanan persuasif, pembatasan terselubung, pembatasan yang jelas, terstruktur pengaturan makan, dan terstruktur waktu makan. Pola makan anak dikategorikan menjadi 3 kategori, yaitu rendah, sedang, dan tinggi. Data yang telah dikumpulkan diolah dan dianalisis dengan menggunakan analisis deskriptif. Hasil penelitian menunjukkan bahwa 82,5 persen anak memiliki pola makan pada kategori sedang. Hasil ini menunjukan bahwa pola makan anak berada pada kategori belum optimal. Oleh karena itu, orang tua dan guru diharapkan dapat meningkatkan perhatian pada pola makan anak. Orang tua dan guru diharapkan dapat mengajarkan anak mengenai pola makan yang sehat.
\end{abstract}

Kata kunci: anak usia sekolah, keterlibatan keluarga, pola makan, makanan sehat

\section{Analysis of Eating Pattern in School Aged Children}

\section{Abstrack}

Food consumed by school age children greatly affects physical development. Parents have a role to the control and supervision related to child's eating patterns because school age children vulnerable to disease, especially nutrition problems. The purpose of this study is to describe and analyze eating pattern in school age children. The research was conducted in december, 2019. This study involved 97 students at SDN Sumur Batu 01 Pagi Kemayoran, Jakarta that were selected using stratified sampling technique. Eating pattern have been measured using the feeding practices and structure questionnaire (FPSQ) instrument (Jansen, Mallan, Nicholson, \& Daniels, 2014). Children's eating patterns were seen based on 8 dimensions, namely: distrust in appetite, reward for behavior, reward for eating, persuasive feeding, covert restriction, overt restriction, structured meal setting, and structured meal timing. Children's eating patterns are categorized into 3 categories, namely low, medium, and high. The data that has been collected is processed and analyzed using descriptive analysis. The results showed that 82,5 percent of children had a moderate eating pattern. These results indicate that children's eating patterns are still not optimal. Therefore, parents and teachers are expected to be able to increase attention to children's eating patterns. Parents and teachers are expected to be able to teach children about healthy eating patterns.

Keywords: eating pattern, family involvement, healthy food, school aged children

\section{PENDAHULUAN}

Kualitas anak-anak Indonesia merupakan penentu kualitas Sumber Daya Manusia (SDM) di masa mendatang. Anak akan menjadi generasi penerus pembangunan bangsa. Salah satu 
penentu kualitas sumber daya manusia adalah pertumbuhan dan perkembangan di usia awal. SDM yang berkualitas adalah sumber daya manusia yang sehat, cerdas, dan produktif ditentukan oleh beberapa faktor, salah satunya adalah terpenuhinya kebutuhan pangan yang bergizi dan tercapainya status gizi optimal. Status gizi pada anak usia sekolah sangat perlu diperhatikan, orangtua sangat berperan penting dalam pemenuhan gizi anak (Nuzrina, Melani, \& Ronitawati, 2016).

Saat ini, masalah gizi yang terjadi pada anak usia sekolah di Indonesia masih cukup tinggi. Berdasarkan hasil Pemantauan Status Gizi (Kemenkes RI, 2017) didapatkan status gizi anak umur 5-12 tahun menurut indeks massa tubuh/umur (IMT/U) di Indonesia yaitu prevalensi kurus adalah 10,9\%, terdiri dari 3,4\% sangat kurus dan 7,5\% kurus. Gizi yang baik merupakan pondasi bagi kesehatan masyarakat terutama anak-anak yang masih dalam masa pertumbuhan dan perkembangan, jika terjadi gangguan gizi kurang maupun gizi lebih maka pertumbuhan dan perkembangan tidak akan berlangsung secara optimal. Gangguan gizi kurang memberikan dampak negatif seperti menurunnya fungsi kognitif, menghambat pertumbuhan fisik sehingga daya tahan tubuh cenderung melemah dan postur tubuh cenderung pendek. Sedangkan jika gangguan gizi lebih akan mengakibatkan dampak negatif seperti meningkatknya risiko terjangkit penyakit degeneratif.

Hayatus, Herman, dan Sastri (2014) mengatakan bahwa status gizi baik mempengaruhi pertumbuhan dan perkembangan anak, anak usia sekolah membutuhkan gizi baik untuk menunjang kegiatan belajar di sekolah. Asupan gizi baik dapat mempengaruhi daya konsentrasi dan kemampuan kognitif sehingga dapat meningkatkan prestasi belajar anak di sekolah. Anak usia sekolah merupakan sasaran yang strategis dalam perbaikan gizi masyarakat. Hal ini menjadi penting karena pada fase anak usia sekolah tumbuh kembang anak sedang berproses secara optimal.

Faktor penyebab terjadinya kekurangan gizi adalah ketidakseimbangan gizi dalam makanan yang dikonsumsi dan terjangkitnya penyakit infeksi. Penyebab tidak langsung adalah ketahanan pangan di keluarga, pola pengasuhan anak dan pelayanan kesehatan. Ketiga faktor tersebut berkaitan dengan tingkat pendidikan, pengetahuan dan keterampilan keluarga serta tingkat pendapatan keluarga (Elisa, 2012). Selain itu, anak usia sekolah seringkali mengalami penurunan nafsu makan sehingga asupan makanan yang dikonsumsi menjadi tidak seimbang dengan kalori yang diperlukan oleh tubuh dan tidak sesuai dengan angka kecukupan gizi berdasarkan usia menurut jenis kelamin (Octaviani, Izhar, \& Amir, 2018). Pada saat ini, pola makan anak sudah mengarah ke pola makan cepat saji dimana makanan cepat saji mengandung banyak kalori dan menyebabkan anak menjadi obesitas (Widyantari, Nuryanto, \& Dewi, 2018). Penelitian yang dilakukan Ningsih (2016) memaparkan bahwa masih ada anak yang mengalami masalah gizi, baik itu gizi kurang maupun gizi lebih.

Anzarkusuma et al., (2014) mengatakan bahwa pola asupan makanan dan pengaturan makanan penting untuk dilakukan karena dapat mempengaruhi pertumbuhan dan perkembangan fisik anak. Sebagai upaya untuk memenuhi kebutuhan gizi dan mengoptimalkan perkembangan fisik, dibutuhkan pengetahuan gizi bagi orang tua untuk dapat menimplementasikan pola makan yang baik (Yulia, Khomsan, Sukandar, \& Riyadi, 2018). Pola makan terkait dengan pemilihan jajanan dapat mempengaruhi kualitas gizi anak. Pola makan anak dipengaruhi oleh pengetahuan orang tua, edukasi yang diberikan orang tua terkait pemenuhan gizi seimbang dan kebiasaan pola makan yang terstruktur. Kebiasaan baik yang dapat orang tua lakukan ialah membudayakan sarapan pagi. Dampak positif sarapan dapat memenuhi asupan gizi yang dibutuhkan anak per harinya. Anak yang tidak sarapan akan berisiko mengalami defisiensi zat gizi (Noviani, Afifah, \& Astiti, 2016).

Apabila anak usia sekolah tidak bijak dalam melakukan pemilihan makanan, dapat terserang penyakit. Salah satunya ialah radang tonsillitis, pemicu radang tonsillitis adalah mengkonsumsi makanan dan minuman yang tidak bersih (higienis). Gejala tonsilitis atau radang amandel menimbulkan demam, tenggorokan kering, menggigil, lemas, nyeri otot, batuk 
pilek, ada rasa mengganjal di leher, nyeri saat menelan ludah atau makanan dan minuman sehingga menjadi malas makan. Nyeri ketika tonsilitis meradang dapat menjalar ke sekitar leher dan telinga (Arsyad, Wahyuni, \& Ipa, 2013). Oleh karena itu, kajian mengenai pola makan pada anak usia sekolah perlu untuk dilakukan. Penelitian ini bertujuan untuk mendeskripsikan dan menganalisis pola makan pada anak usia sekolah di SDN. Sumur Batu 01 Pagi Kemayoran, Jakarta.

\section{METODE}

Penelitian ini merupakan penelitian deskriptif. Pengumpulan data penelitian dilakukan pada bulan Desember tahun 2019. Penelitian ini melibatkan 97 orang siswa di SDN Sumur Batu 01 Pagi, Kecamatan Kemayoran, DKI Jakarta yang dipilih dengan mengunakan teknik stratified sampling. Data yang akan dikumpulkan dalam penelitian ini adalah pola makan. Data dikumpulkan dengan teknik pelaporan diri (self report). Pola makan pada anak usia sekolah diukur menggunakan instrumen The Feeding Practices and Structure Quistionnare (FPSQ) (Jansen, Mallan, Nicholson, \& Daniels, 2014). Instrumen tersebut terdiri atas delapan dimensi, yaitu ketidakpercayaan nafsu makan, hadiah untuk perilaku, hadiah untuk makan, makanan persuasif, pembatasan terselubung, pembatasan yang jelas, terstruktur pengaturan makan, dan terstruktur waktu makan. Instrumen tersebut terdiri atas 24 pernyataan dengan pilihan tanggapan, terdiri atas: tidak pernah, jarang, kadang-kadang, sering, dan selalu. Skor yang diperoleh dijumlahkan dan dikonversikan dalam bentuk indeks. Setelah itu, data dikategorikan menjadi tiga kategori, yaitu rendah (indeks<60), sedang (indeks 60-80), dan tinggi (indeks $>80$ ). Selanjutnya, data diolah dan dianalisis dengan menggunakan analisis deskriptif.

\section{HASIL DAN PEMBAHASAN}

\section{Karakteristik Anak}

Anak usia sekolah yang terlibat dalam penelitian ini berjenis kelamin perempuan $(51 \%)$ dan laki-laki (46\%). Usia anak berada pada rentang 9-12 tahun. Sebagian besar anak berusia 11 tahun dengan usia rata-rata adalah 11,10 tahun.

\section{Pola Makan Anak Usia Sekolah}

Dimensi Ketidakpercayaan Nafsu Makan. Dimensi ketidakpercayaan nafsu makan adalah dimensi yang berkaitan dengan kemandirian anak dalam memenuhi makanan bekal sekolah serta fasilitas yang diberikan orang tua dalam implementasi pola makan anak (Jansen et al., 2014). Hasil penelitian disajikan pada Tabel 1.

Tabel 1 Pola makan anak pada dimensi ketidakpercayaan nafsu makan

\begin{tabular}{|c|c|c|c|c|c|c|c|}
\hline \multirow{2}{*}{ No } & \multirow{2}{*}{ Pernyataan } & \multicolumn{5}{|c|}{ Jawaban (\%) } & \multirow{2}{*}{ Tota } \\
\hline & & 1 & 2 & 3 & 4 & 5 & \\
\hline 1 & Menyiapkan bekal sekolah secara mandiri & 22,7 & 22,7 & 36,1 & 9,3 & 9,3 & 100 \\
\hline 2 & $\begin{array}{l}\text { Mengkonsumsi makanan dalam jumlah } \\
\text { banyak jika diperintah orangtua }\end{array}$ & 8,2 & 14,4 & 18,6 & 23,7 & 35,1 & 100 \\
\hline 3 & $\begin{array}{l}\text { Berani menolak ajakan teman dalam } \\
\text { konsumsi makanan tidak sehat }\end{array}$ & 8,2 & 11,3 & 14,4 & 35,1 & 30,9 & 100 \\
\hline 4 & $\begin{array}{l}\text { Konsumsi makanan dengan jumlah } \\
\text { makanan yang diatur oleh orang tua }\end{array}$ & 35,1 & 11,3 & 14,4 & 15,5 & 23,7 & 100 \\
\hline 5 & $\begin{array}{l}\text { Orang tua marah ketika anak menolak } \\
\text { makanan }\end{array}$ & 8,4 & 21,1 & 24,2 & 18,9 & 27,4 & 100 \\
\hline
\end{tabular}

Keterangan: 1=tidak pernah, 2=jarang, 3=kadang=kadang, 4=sering 5=selalu 
Data yang disajikan pada Tabel 1 menunjukkan bahwa anak menjawab sering $(9,3 \%)$ dan selalu $(9,3 \%)$ untuk pertanyaan menyiapkan bekal sekolah secara mandiri. Hasil ini menunjukkan bahwa seimbang, anak yang menyiapkan sendiri makanan sebagai bekal makan di sekolah. Ningsih, Restuastuti, \& Suyanto (2016) anak usia sekolah cenderung gemar jajan makanan yang dijual di lingkungan sekolah karena makanan tersebut berwarna menarik dan memakai pemanis buatan sehingga anak lebih memilih untuk jajan di sekolah dibandingkan dengan menyiapkan bekal makan sekolah secara mandiri. Selanjutnya, anak menjawab sering $(23,7 \%)$ dan selalu $(35,1 \%)$ untuk pertanyaan mengkonsumsi makanan dalam jumlah banyak jika diperintah orangtua. Hasil ini menunjukkan bahwa sebagian besar anak makan lebih sedikit jika tidak diperintah orang tua. Anak usia sekolah cenderung memilih jajanan dibandingkan dengan mengkonsumsi makanan pokok atau makanan sehat karena kegemarannya dalam mengkonsumsi makanan cepat saji, snack dan minuman soft drink (Amourisva, 2015).

Dalam hal ini orang tua memiliki peran untuk memberikan pengawasan kepada anak agar dapat mengkonsumsi makanan pokok sesuai dengan kebutuhan asupan gizi dan kalori tubuh sehari-hari untuk mengoptimalkan pertumbuhan dan perkembangan anak. Selanjutnya, anak menjawab sering $(35,1 \%)$ dan selalu $(30,9 \%)$ untuk pertanyaan berani menolak ajakan teman dalam konsumsi makanan tidak sehat. Hasil ini menunjukkan bahwa masih banyak anak yang sering menolak ajakan teman dan berani berkata "tidak" untuk membeli makanan yang tidak sehat. Makanan atau jajanan yang tidak sehat adalah jajanan atau makanan yang mengandung bahan kimia berbahaya yang dijual di lingkungan rumah dan sekolah. Pengaruh teman sebaya memiliki peranan yang besar dalam pemilihan jajan anak karena pada masa usia sekolah, anak cenderung memiliki waktu yang lebih banyak saat bermain dengan teman sebaya (Kustriyani, Widyaningsih, \& Prasertyo, 2017).

Sehingga untuk menyiasati kondisi tersebut, orang tua memiliki peran untuk memberikan pengetahuan kepada anak terkait pemilihan makanan sehat, mengedukasi anak untuk menumbuhkan sikap berani dan menanamkan pendirian yang kuat kepada anak agar anak mampu berkata "tidak" ketika mendapat ajakan yang tidak sesuai dengan nilai-nilai yang tidak sesuai dengan dirinya. Selanjutnya, anak menjawab sering $(15,5 \%)$ dan selalu $(23,7 \%)$ untuk pertanyaan konsumsi makanan dengan jumlah makanan yang diatur oleh orang tua. Hasil ini menunjukkan bahwa sebagian besar orang tua memberlakukan pengaturan jumlah makanan yang harus dimakan oleh anak.

Pengaturan makanan (jumlah makanan, variasi makanan, waktu makan) sangatlah penting untuk dilakukan oleh orang tua karena dapat mempengaruhi pertumbuhan dan perkembangan fisik anak. Oleh karena itu, kebiasaan makan yang baik perlu diimplementasikan sejak dini (Anzarkusuma et al., 2014). Selanjutnya, anak menjawab sering $(18,9 \%)$ dan selalu $(27,4 \%)$ untuk pertanyaan orang tua marah ketika anak menolak makanan. Hasil ini menunjukkan bahwa masih banyak anak yang selalu dimarahi oleh orang tua ketika menolak makanan yang biasa anak makan. Dalam mengatur pola makan anak, orang tua harus memiliki strategi dan bijak dalam mengatur pola makan anak, agar anak tidak merasa tertekan. Apabila anak menolak untuk makan makanan yang biasa anak makan, sebaiknya orang tua menanyakan alasan anak dan melakukan komunikasi dua arah agar saling mengerti dan memahami.

Secara keseluruhan, pola makan anak berdasarkan dimensi ketidakpercayaan nafsu makan dapat dikategorikan belum optimal. Orang tua memiliki peran untuk meningkatkan pola makan anak dengan memberikan edukasi terkait pemenuhan gizi seimbang, asupan nutrisi yang dibutuhkan anak sehingga menumbuhkan kepedulian anak akan pemenuhan gizi tubuhnya dengan membawa bekal sehat ke sekolah, mengkonsumsi jumlah makanan sesuai dengan kebutuhan dan berani menolak ajakan teman dalam mengkonsumsi makanan tidak sehat. Hasil penelitian disajikan pada Tabel 2. 
Tabel 2 Kategori pola makan anak berdasarkan dimensi ketidakpercayaan nafsu makan

\begin{tabular}{clcc}
\hline No & Kategori & Jumlah & Persentase (\%) \\
\hline 1. & Rendah & 25 & 25,8 \\
2. Sedang & 65 & 67,0 \\
3. & Tinggi & 7 & 7,2 \\
\hline Total & 97 & 100 \\
Nilai Minimal-Maksimal & \multicolumn{2}{c}{$0,00-88,00$} \\
Nilai Rata - Rata \pm Standar Deviasi & \multicolumn{2}{c}{$62,16 \pm 16,26$} \\
\hline
\end{tabular}

Dimensi Hadiah untuk Perilaku. Dimensi hadiah untuk perilaku adalah dimensi yang berkaitan dengan pemberian hadiah yang diberikan oleh orang tua, baik dalam bentuk barang maupun makanan ketika anak melakukan perilaku baik (Jansen et al., 2014). Hasil penelitian disajikan pada Tabel 3.

Tabel 3 Pola makan anak pada dimensi hadiah untuk perilaku

\begin{tabular}{clcccccc}
\hline \multirow{2}{*}{ No } & \multicolumn{2}{c}{ Pernyataan } & \multicolumn{5}{c}{ Jawaban (\%) } \\
\cline { 3 - 7 } & \multicolumn{1}{c}{ Total } \\
\hline 1 & $\begin{array}{l}\text { Orang tua menawarkan makanan manis } \\
\text { (seperti: permen, es krim, kue dan kue }\end{array}$ & 8,2 & 14,4 & 37,1 & 25,8 & 14,4 & 100 \\
kering) sebagai hadiah & & & & & \\
2 & $\begin{array}{l}\text { Orang tua memberikan makanan ketika } \\
\text { berperilaku baik }\end{array}$ & 26,8 & 24,7 & 10,3 & 22,7 & 15,5 & 100 \\
3 & $\begin{array}{l}\text { Orang tua memberikan makanan ketika anak } \\
\text { merasa kesal }\end{array}$ & 16,5 & 18,6 & 23,7 & 14,4 & 26,8 & 100 \\
\hline
\end{tabular}

Keterangan: $1=$ tidak pernah, 2=jarang, 3=kadang=kadang, 4=sering 5=selalu

Data yang disajikan pada Tabel 3 menunjukkan bahwa anak menjawab sering $(25,8 \%)$ dan selalu $(14,4 \%)$ untuk pertanyaan orang tua menawarkan makanan manis (seperti: permen, es krim, kue dan kue kering) sebagai hadiah. Hasil ini menunjukkan bahwa masih banyak orang tua yang selalu menawarkan makanan manis (seperti: permen, es krim, kue dan kue kering) sebagai hadiah. Selanjutnya, anak menjawab sering $(22,7 \%)$ dan selalu $(15,5 \%)$ untuk pertanyaan orang tua memberikan makanan ketika berperilaku baik. Hasil ini menunjukkan bahwa sebagian besar orang tua selalu memberikan makanan agar anak berbuat baik. Berkaitan dengan dua butir pertanyaan tersebut, memberikan reward kepada anak atas perilaku yang baik memang dapat memberikan motivasi positif karena anak merasa dihargai dan dicintai. Namun, dalam memberikan reward, orang tua harus mempertimbangkan intensitas pemberian reward serta bentuk reward tersebut.

Pada dasarnya reward yang diberikan atas perilaku baik bukan hanya berupa barang atau makanan melainkan kalimat-kalimat pujian dan kasing sayang juga termasuk sebagai reward yang memberikan motivasi positif bagi anak. Selanjutnya, anak menjawab sering $(14,4 \%)$ dan selalu $(26,8 \%)$ untuk pertanyaan ketika kamu merasa kesal, orang tua memberikan makanan ketika anak merasa kesal. Hasil ini menunjukkan bahwa sebagian besar anak selalu diberikan makanan oleh orang tua ketika merasa kesal. Dalam situasi tersebut, orang tua harus bijak dalam melakukan tindakan, pemberian makanan bukan solusi yang tepat untuk meredakan emosi negatif anak. Upaya yang dapat orang tua lakukan ialah memberikan pelukan dan belaian kasih sayang, anak akan merasa dicintai dan dihargai keberadaannya sehingga dapat menumbuhkan emosi positif pada anak.

Secara keseluruhan, pola makan anak berdasarkan dimensi hadiah untuk perilaku dapat dikategorikan belum optimal. Dalam hal ini orang tua yang memiliki peran untuk bijak dalam memberikan batasan hadiah terkait dengan perilaku baik anak, meredakan emosi negatif anak dan memperhatikan intensitas pemberian hadiah kepada anak. Hasil penelitian disajikan pada Tabel 4. 
Tabel 4 Kategori pola makan anak berdasarkan dimensi hadiah untuk perilaku

\begin{tabular}{clcc}
\hline No & Kategori & Jumlah & Persentase (\%) \\
\hline 1. & Rendah & 42 & 43,3 \\
2. & Sedang & 42 & 43,3 \\
3. & Tinggi & 13 & 13,4 \\
\hline Total & 97 & 100 \\
Nilai Minimal-Maksimal & \multicolumn{2}{c}{$0,00-100,00$} \\
Nilai Rata - Rata \pm Standar Deviasi & \multicolumn{2}{c}{$59,20 \pm 21,17$} \\
\hline
\end{tabular}

Dimensi Hadiah untuk Makan. Dimensi hadiah untuk makan adalah dimensi yang berkaitan dengan pemberian hadiah yang diberikan orang tua apabila anak mampu mengikuti pola makan yang diterapkan orang tua (Jansen et al., 2014). Hasil penelitian disajikan pada Tabel 5.

Tabel 5 Pola makan anak pada dimensi hadiah untuk makan

\begin{tabular}{clcccccc}
\hline \multirow{2}{*}{ No } & \multirow{2}{*}{ Pernyataan } & \multicolumn{5}{c}{ Jawaban (\%) } & Total \\
\cline { 3 - 6 } & \multicolumn{1}{c}{$\begin{array}{c}\text { Orang tua memberikan hadiah ketika anak } \\
\text { menolak makanan }\end{array}$} & 6,2 & 9,3 & 8,2 & 17,5 & 58,8 & 100 \\
2 & $\begin{array}{l}\text { Orang tua memberikan makanan dalam bentuk } \\
\text { hadiah }\end{array}$ & 6,2 & 7,2 & 21,6 & 24,7 & 40,2 & 100 \\
\hline
\end{tabular}

Keterangan: 1 =tidak pernah, 2=jarang, 3=kadang=kadang, 4=sering 5=selalu

Data yang disajikan pada Tabel 5 menunjukkan bahwa anak menjawab sering (17,5\%) dan selalu $(58,8 \%)$ untuk pertanyaan orang tua memberikan hadiah ketika anak menolak makanan. Hasil ini menunjukkan bahwa sebagian besar anak ketika menolak makan, selalu ditawarkan hadiah oleh orang tua agar tetap makan. selanjutnya, anak menjawab sering $(24,7 \%)$ dan selalu $(40,2 \%)$ untuk pertanyaan orang tua memberikan makanan dalam bentuk hadiah. Hasil ini menunjukkan bahwa masih banyak anak yang mendapatkan hadiah berupa makanan dari orang tua. Berkaitan dengan dua butir pertanyaan tersebut, orang tua dapat mengontrol pengaturan makan anak dan perilaku anak dengan tidak menggunakan hadiah berupa makanan ataupun barang dalam mengatur penolakan makan anak (Luh \& Purnama, 2015). Sebagai upaya untuk mendorong asupan makanan anak yang seimbang dan bervariasi, orang tua dapat menyediakan lingkungan, situasi dan kondisi makan yang menyenangkan. Misalnya dengan melibatkan anak dalam pemilihan menu makanan seharihari yang disesuaikan dengan jumlah makanan dan gizi seimbang, melibatkan anak dalam melakukan proses memasak dan memberikan stimulasi kepada anak agar mau mencoba makanan bervariasi yang belum pernah dikonsumsi sebelumnya.

Secara keseluruhan, pola makan anak berdasarkan dimensi hadiah untuk makan dapat dikategorikan optimal. Berkaitan dengan pemberian hadiah untuk makan baiknya orang tua memiliki sikap yang bijak sehingga anak akan lebih mandiri dan sadar akan pemenuhan gizi setiap hari. Kategori pola makan anak berdasarkan dimensi hadiah untuk makan disajikan pada Tabel 6.

Tabel 6 Kategori pola makan anak berdasarkan dimensi hadiah untuk makan

\begin{tabular}{clcc}
\hline No & \multicolumn{1}{c}{ Kategori } & Jumlah & Persentase $(\%)$ \\
\hline 1. & Rendah & 12 & 12,4 \\
2. & Sedang & 34 & 35,1 \\
3. & Tinggi & 51 & 51,0 \\
\hline Total & 97 & 100 \\
Nilai Minimal-Maksimal & \multicolumn{2}{c}{$0,00-100,00$} \\
Nilai Rata - Rata \pm Standar Deviasi & \multicolumn{2}{c}{$77,50 \pm 24,09$} \\
\hline
\end{tabular}


Dimensi Makanan Persuasif. Dimensi makanan persuasif adalah dimensi yang berkaitan dengan usaha dan perilaku orang tua dalam menstimulasi anak terkait dengan pola makan sehari-hari (Jansen et al., 2014). Hasil penelitian disajikan pada Tabel 7.

Tabel 7 Pola makan anak pada dimensi makanan persuasif

\begin{tabular}{|c|c|c|c|c|c|c|c|}
\hline \multirow{2}{*}{ No } & \multirow{2}{*}{ Pernyataan } & \multicolumn{5}{|c|}{ Jawaban (\%) } & \multirow{2}{*}{ Total } \\
\hline & & 1 & 2 & 3 & 4 & 5 & \\
\hline 1 & $\begin{array}{l}\text { Ketika anak merasa lapar orang tua } \\
\text { membujuknya }\end{array}$ & 8,2 & 13,4 & 16,5 & 24,7 & 37,1 & 100 \\
\hline 2 & $\begin{array}{l}\text { Ketika anak mengkonsumsi makanan yang } \\
\text { telah disajikan orang tua, orang tua } \\
\text { memberikan pujian }\end{array}$ & 23,7 & 17,5 & 26,8 & 13,4 & 18,6 & 100 \\
\hline 3 & $\begin{array}{l}\text { Ketika anak menolak makanan, orang tua } \\
\text { menunjukkan sikap kesal }\end{array}$ & 4,1 & 12,4 & 23,7 & 23,7 & 36,1 & 100 \\
\hline
\end{tabular}

Keterangan: 1 =tidak pernah, $2=$ jarang, 3 =kadang=kadang, $4=$ sering $5=$ selalu

Data yang disajikan pada Tabel 7 menunjukkan bahwa anak menjawab sering (24,7\%) dan selalu $(37,1 \%)$ untuk pertanyaan ketika anak merasa lapar orang tua membujuknya. Hasil ini menunjukkan bahwa sebagian besar anak selalu dibujuk orang tua ketika anak merasa lapar. Dalam memfasilitasi pola makan anak, orang tua dapat memberikan perhatian kepada anak agar anak makan sesuai dengan jadwal makan sehingga terpenuhi jumlah supan gizi dan kalori yang dibutuhkan dalam proses pertumbuhan dan perkembangan fisiknya. Selanjutnya, anak menjawab sering $(18,6 \%)$ dan selalu $(13,4 \%)$ untuk pertanyaan ketika anak mengkonsumsi makanan yang telah disajikan orang tua, orang tua memberikan pujian. Hasil ini menunjukkan bahwa masih banyak orang tua yang memberikan pujian ketika anak memakan makanan yang disiapkan olehnya. Upaya yang dapat orang tua lakukan ialah memberikan pujian rasa bangga dan ucapan terima kasih karena anak menghargai usaha yang dilakukan oleh orang tua dalam meyediakan makanan sehari-hari. Selanjutnya, anak menjawab sering $(23,7 \%)$ dan selalu $(36,1 \%)$ untuk pertanyaan ketika anak menolak makanan, orang tua menunjukkan sikap kesal. Hasil ini menunjukkan bahwa masih banyak orang tua yang memarahi anak ketika anak menolak makan. Dalam situasi tersebut, komunikasi positif adalah upaya yang dapat orang tua lakukan dalam menjaga pola makan anak. Berikan kesempatan kepada anak untuk mengutarakan alasan menolak makanan, apabila anak menolak makanan karena kondisi picky eater, maka orang tua dapat melatih anak secara bertahap dengan mengenalkan berbagai variasi makanan (Anggraini, 2014).

Secara keseluruhan, pola makan anak berdasarkan dimensi makanan persuasif dapat dikategorikan belum optimal. Berkaitan dengan makanan persuasif, orang tua dapat membuat kondisi dan suasana makan yang menyenangkan agar anak tidak merasa tertekan. Berikan dukungan positif kepada anak agar anak dapat mengkonsumsi makanan yang disajikan oleh orang tua. Kategori pola makan anak berdasarkan dimensi makanan persuasive disajikan pada Tabel 8.

Tabel 8 Kategori pola makan anak berdasarkan dimensi makanan persuasif

\begin{tabular}{clcc}
\hline No & Kategori & Jumlah & Persentase $(\%)$ \\
\hline 1. & Rendah & 21 & 21,6 \\
2. & Sedang & 56 & 57,7 \\
3. & Tinggi & 20 & 20,6 \\
\hline Total & 97 & 100 \\
Nilai Minimal-Maksimal & \multicolumn{2}{c}{$33,33-100,00$} \\
Nilai Rata - Rata \pm Standar Deviasi & \multicolumn{3}{c}{$68,65 \pm 16,39$} \\
\hline
\end{tabular}

Dimensi Pembatasan Terselubung. Dimensi pembatasan terselubung adalah dimensi yang berkaitan dengan larangan orang tua dalam pembelian makanan yang tidak sehat (Jansen et al., 2014). Hasil penelitian disajikan pada Tabel 9. 
Tabel 9 Pola makan anak pada dimensi pembatasan terselubung

\begin{tabular}{|c|c|c|c|c|c|c|c|}
\hline \multirow{2}{*}{ No } & \multirow{2}{*}{ Pernyataan } & \multicolumn{5}{|c|}{ Jawaban (\%) } & \multirow{2}{*}{ Total } \\
\hline & & 1 & 2 & 3 & 4 & 5 & \\
\hline 1 & $\begin{array}{l}\text { Orang tua menghindari pembelian makanan } \\
\text { yang tidak sehat }\end{array}$ & 5,2 & 8,2 & 8,2 & 29,9 & 48,5 & 100 \\
\hline 2 & $\begin{array}{l}\text { Orang tua tidak mengkonsumsi makanan } \\
\text { yang dilarang untuk anaknya }\end{array}$ & 16,5 & 5,2 & 14,4 & 24,7 & 39,2 & 100 \\
\hline
\end{tabular}

Keterangan: 1 =tidak pernah, 2 =jarang, 3=kadang=kadang, $4=$ sering $5=$ selalu

Data yang disajikan pada Tabel 9 menunjukkan bahwa anak menjawab sering (29,9\%) dan selalu $(48,5 \%)$ untuk pertanyaan orang tua menghindari pembelian makanan yang tidak sehat. Hasil ini menunjukkan bahwa masih banyak orang tua yang menghindari tempat makan yang menjual makanan tidak sehat. Faktor yang mempengaruhi pola perilaku adalah pendidikan dan pengetahuan, orang tua yang memiliki pendidikan dan pengetahuan terkait pentingnya mengkonsumsi makanan sehat dapat memberikan edukasi kepada anak untuk menghindari pembelian makanan yang tidak sehat karena dapat berdampak buruk bagi kesehatan dan berisiko mengalami masalah gizi (Kustriyani et al., 2017). Selanjutnya, anak menjawab sering $(24,7 \%)$ dan selalu $(39,2 \%)$ untuk pertanyaan orang tua tidak mengkonsumsi makanan yang dilarang untuk anaknya. Hasil ini menunjukkan bahwa masih banyak orang tua yang tidak membeli makanan yang mereka larang terhadap anaknya. Orang tua yang sedang melakukan pengawasan terhadap pola makan anak, seringkali membatasi dan melarang anak untuk mengkonsumsi makanan dan minuman tidak sehat seperti minuman bersoda yang berlebihan serta makanan berupa keripik, kue kering dan permen (Iklima, 2017). Dalam hal ini, orang tua bukan hanya melarang anak tetapi juga turut membantu anak dengan tidak mengkonsumsi makanan dan minuman yang dilarangnya.

Secara keseluruhan, pola makan anak berdasarkan dimensi pembatasan terselubung dikategorikan belum optimal. Berkaitan dengan pembatasan terselubung, orang tua yang berperan mengontrol dan mengawasi pola makan anak hendaknya memberikan dukungan kepada anak dengan tidak mengkonsumsi makanan yang tidak sehat karena anak akan cenderung mengikuti perilaku orang tua. Hasil penelitian disajikan pada Tabel 10.

Tabel 10 Kategori pola makan anak berdasarkan pembatasan terselubung

\begin{tabular}{clcc}
\hline No & Kategori & Jumlah & Persentase (\%) \\
\hline 1. & Rendah & 13 & 13,4 \\
2. & Sedang & 46 & 47,4 \\
3. & Tinggi & 38 & 39,2 \\
\hline Total & 97 & 100 \\
Nilai Minimal-Maksimal & \multicolumn{2}{c}{$0,00-100,00$} \\
Nilai Rata - Rata \pm Standar Deviasi & \multicolumn{2}{c}{$75,00 \pm 25,12$} \\
\hline
\end{tabular}

Dimensi Pembatasan yang Jelas. Dimensi pembatasan yang jelas adalah dimensi yang berkaitan dengan larangan dan batasan yang diberikan oleh orang tua dalam mengkonsumsi makanan yang digemari anak (Jansen et al., 2014). Hasil penelitian disajikan pada Tabel 11. Data yang disajikan pada Tabel 11 menunjukkan bahwa anak menjawab sering (12,4\%) dan selalu $(10,3 \%)$ untuk pertanyaan orang tua melarang anak mengkonsumsi makanan manis seperti (ice cream, permen). Hasil ini menunjukkan bahwa masih banyak orang tua yang melarang anak untuk mengkonsumsi makanan manis. Makanan manis memiliki risiko terjadinya karies gigi dan gigi berlubang (Iklima, 2017). Upaya yang dapat orang tua lakukan adalah mengedukasi dan membatasi anak dalam mengkonsumsi makanan manis secara berlebihan. Selanjutnya, anak menjawab sering $(11,3 \%)$ dan selalu $(7,2 \%)$ untuk pertanyaan orang tua melarang anak mengkonsumsi makanan favorit. Hasil ini menunjukkan bahwa masih terdapat orang tua yang melarang anak mengkonsumsi makanan favorit. Anak usia sekolah cenderung menyukai junk food, minuman bersoda, dan makanan yang kaya akan karbohidrat 
serta protein hewani (Yurni \& Sinaga, 2018). Selanjutnya, anak menjawab sering $(24,7 \%)$ dan selalu $(45,4 \%)$ untuk pertanyaan orang tua membatasi anak mengkonsumsi makanan yang tidak sehat. Hasil ini menunjukkan bahwa masih banyak orang tua yang membatasi anak dalam mengkonsumsi makanan tidak sehat. Makanan tidak sehat dapat berdampak buruk bagi kesehatan, sedangkan makanan jajanan yang sehat dan bergizi dapat menambah asupan energi dan zat gizi bagi anak usia sekolah (Hamida, 2012). Oleh karena itu orang tua memiliki peranan penting untuk memberikan dan menyediakan makanan atau jajanan yang bergizi untuk dapat membantu pertumbuhan anak.

Tabel 11 Pola makan anak pada dimensi pembatasan yang jelas

\begin{tabular}{|c|c|c|c|c|c|c|c|}
\hline \multirow[b]{2}{*}{ No } & \multirow[b]{2}{*}{ Pernyataan } & \multicolumn{5}{|c|}{ Jawaban (\%) } & \multirow{2}{*}{ Total } \\
\hline & & 1 & 2 & 3 & 4 & 5 & \\
\hline 1 & $\begin{array}{l}\text { Orang tua melarang anak mengkonsumsi } \\
\text { makanan manis seperti (ice cream, permen) }\end{array}$ & 25,8 & 23,7 & 27,8 & 12,4 & 10,3 & 100 \\
\hline 2 & $\begin{array}{l}\text { Orang tua melarang anak mengkonsumsi } \\
\text { makanan favorit }\end{array}$ & 32,0 & 24,7 & 24,7 & 11,3 & 7,2 & 100 \\
\hline 3 & $\begin{array}{l}\text { Orang tua membatasi anak mengkonsumsi } \\
\text { makanan yang tidak sehat }\end{array}$ & 9,3 & 9,3 & 11,3 & 24,7 & 45,4 & 100 \\
\hline
\end{tabular}

Keterangan: 1=tidak pernah, 2=jarang, 3=kadang=kadang, 4=sering 5=selalu

Secara keseluruhan hasil dari pola makan anak berdasarkan dimensi pembatasan yang jelas dikategorikan belum optimal. Kategori pola makan anak berdasarkan pembatasan yang jelas disajikan pada Tabel 12.

Tabel 12 Kategori pola makan anak berdasarkan pembatasan yang jelas

\begin{tabular}{clcc}
\hline No & \multicolumn{1}{c}{ Kategori } & Jumlah & Persentase (\%) \\
\hline 1. & Rendah & 13 & 13,4 \\
2. & Sedang & 46 & 47,4 \\
3. & Tinggi & 38 & 39,2 \\
\hline Total & 97 & 100 \\
Nilai Minimal-Maksimal & \multicolumn{2}{c}{$0,00-100,00$} \\
Nilai Rata - Rata \pm Standar Deviasi & \multicolumn{2}{c}{$75,00 \pm 25,12$} \\
\hline
\end{tabular}

Dimensi Terstruktur Pengaturan Makan. Dimensi terstruktur pengaturan makan adalah dimensi yang berkaitan dengan etika makan (Jansen et al., 2014). Hasil penelitian tentang pola makan anak usia sekolah pada dimensi terstruktur pengaturan makanan disajikan pada Tabel 13.

Tabel 13 Pola makan anak pada dimensi terstruktur pengaturan makanan

\begin{tabular}{|c|c|c|c|c|c|c|c|}
\hline \multirow{2}{*}{ No } & \multirow{2}{*}{ Pernyataan } & \multicolumn{5}{|c|}{ Jawaban (\%) } & \multirow{2}{*}{ Total } \\
\hline & & 1 & 2 & 3 & 4 & 5 & \\
\hline 1 & $\begin{array}{l}\text { Anak diberi izin orang tua untuk makan dan } \\
\text { berkeliling }\end{array}$ & 3,1 & 7,2 & 8,2 & 11,3 & 70,1 & 100 \\
\hline 2 & $\begin{array}{l}\text { Anak dibujuk orang tua untuk mengkonsumsi } \\
\text { makanan yang telah disiapkan }\end{array}$ & 15,5 & 8,2 & 16,5 & 27,8 & 32,0 & 100 \\
\hline 3 & Anak makan dengan duduk & 0 & 3,1 & 6,2 & 22,7 & 68,0 & 100 \\
\hline
\end{tabular}

Data yang disajikan pada Tabel 13 menunjukkan bahwa anak menjawab sering $(11,3 \%)$ dan selalu $(70,1 \%)$ untuk pertanyaan anak diberi izin orang tua untuk makan dan berkeliling. Hasil ini menunjukkan bahwa sebagian besar orang tua mengizinkan anak berkeliling saat makan. Selanjutnya, anak menjawab sering $(27,8 \%)$ dan selalu $(32,0 \%)$ untuk pertanyaan anak dibujuk orang tua untuk mengkonsumsi makanan yang telah disiapkan. Hasil menunjukkan bahwa masih banyak orang tua yang membujuk anak makan makanan yang 
sudah disiapkan di meja. Selanjutnya, anak menjawab sering (22,7\%) dan selalu (68\%) untuk pertanyaan anak makan dengan duduk. Hasil menunjukkan bahwa sebagian besar anak duduk ketika melakukan makan. Berkaitan dengan 3 butir pertanyaan tersebut, (Luh \& Purnama, 2015) mengatakan orang tua bukan hanya mengontrol pola makan anak, tetapi memberikan edukasi terkait dengan etika makan, agar anak dapat memahami batasan dan menghargai makanan serta orang-orang disekitarnya.

Secara keseluruhan hasil dari pola makan anak berdasarkan dimensi terstruktur pengaturan waktu makan dikategorikan belum optimal. Kategori pola makan anak berdasarkan dimensi terstruktur pengaturan makan disajikan pada Tabel 14.

Tabel 14 Kategori pola makan anak berdasarkan dimensi terstruktur pengaturan makan

\begin{tabular}{clcc}
\hline No & Kategori & Jumlah & Persentase (\%) \\
\hline 1. & Rendah & 5 & 5,2 \\
2. Sedang & 37 & 38,1 \\
3. & Tinggi & 55 & 56,7 \\
\hline Total & 97 & 100 \\
Nilai Minimal-Maksimal & \multicolumn{2}{c}{$0,00-100,00$} \\
Nilai Rata - Rata \pm Standar Deviasi & \multicolumn{2}{c}{$80,60 \pm 20,12$} \\
\hline
\end{tabular}

Dimensi Terstruktur Waktu Makan. Dimensi struktur waktu makan adalah dimensi yang berkaitan dengan jadwal makan setiap hari dalam memenuhi kebutuhan gizi anak (Jansen et al., 2014). Pola makan anak pada dimensi terstruktur waktu makan disajikan pada Tabel 15.

Tabel 15 Pola makan anak pada dimensi terstruktur waktu makan

\begin{tabular}{|c|c|c|c|c|c|c|c|}
\hline \multirow{2}{*}{ No } & \multirow{2}{*}{ Pernyataan } & \multicolumn{5}{|c|}{ Jawaban } & \multirow{2}{*}{ Tota } \\
\hline & & 1 & 2 & 3 & 4 & 5 & \\
\hline 1 & $\begin{array}{l}\text { Anak diberi kebebasan oleh orang tua terkait } \\
\text { waktu makan }\end{array}$ & 0 & 3,1 & 6,2 & 22,7 & 68,0 & 100 \\
\hline 2 & $\begin{array}{l}\text { Orang tua menentukan camilan yang } \\
\text { dimakan anak }\end{array}$ & 39,2 & 15,5 & 21,5 & 13,4 & 10,3 & 100 \\
\hline 3 & $\begin{array}{l}\text { Penentuan jadwal makan anak diatur oleh } \\
\text { orang tua }\end{array}$ & 49,5 & 9,3 & 10,3 & 14,4 & 16,5 & 100 \\
\hline
\end{tabular}

Keterangan: 1 =tidak pernah, 2=jarang, 3=kadang=kadang, 4=sering 5=selalu

Data yang disajikan pada Tabel 15 menunjukkan bahwa anak menjawab sering $(22,7 \%)$ dan selalu (68\%) untuk pertanyaan anak diberi kebebasan oleh orang tua terkait waktu makan. Hasil menunjukkan bahwa masih banyak orang tua yang membebaskan waktu makan anak. Selanjutnya, anak menjawab sering $(13,4 \%)$ dan $(10,3 \%)$ selalu untuk orang tua menentukan camilan yang dimakan anak. Hasil ini menunjukkan bahwa masih banyak anak orang tua yang menentukan anak dalam konsumsi camilan. Selanjutnya, anak menjawab sering $(14,4 \%)$ dan $(16,5 \%)$ selalu untuk pertanyaan penentuan jadwal makan anak diatur oleh orang tua. Hasil ini menunjukkan bahwa masih banyak orang tua yang menentukan jadwal makan anak setiap hari. Berkaitan dengan tiga butir pertanyaan tersebut, orang tua memiliki peran yang penting dalam menerapkan jadwal makan anak, karena pola makan baik adalah pola makan dengan waktu yang terstruktur. Pola makan yang seimbang yaitu yang sesuai dengan pemilihan makanan yang sesuai dengan kebutuhkan disertai pemilihan bahan makanan yang tepat sebagai upaya mewujudkan status gizi yang baik pada anak usia sekolah (Arifin, 2015).

Secara keseluruhan hasil dari pola makan anak berdasarkan dimensi terstruktur waktu makan dikategorikan belum optimal. Berkaitan dengan pengaturan waktu makan anak, baiknya orang tua selalu disiplin menerapkan jadwal makan. Agar kebutuhan anak sehari-hari dapat terpenuhi. Kategori pola makan anak berdasarkan dimensi terstruktur waktu makan disajikan pada Tabel 16. 
Tabel 16 Kategori pola makan anak berdasarkan dimensi terstruktur waktu makan

\begin{tabular}{clcc}
\hline No & Kategori & Jumlah & Persentase $(\%)$ \\
\hline 1. & Rendah & 50 & 51,5 \\
2. Sedang & 41 & 42,3 \\
3. & Tinggi & 6 & 6,2 \\
\hline Total & 97 & 100 \\
Nilai Minimal-Maksimal & \multicolumn{2}{c}{$0,00-100,00$} \\
Nilai Rata - Rata \pm Standar Deviasi & \multicolumn{2}{c}{$53,18 \pm 20,12$} \\
\hline
\end{tabular}

\section{Kategori Pola Makan}

Pola makan adalah perilaku individu dalam memenuhi kebutuhan asupan gizi sehari-hari meliputi sikap, kepercayaan, dan pilihan makanan sebagai hasil dari pengaruh fisiologis, psikologis, budaya dan sosial. Sebaran anak usia sekolah berdasarkan kategori pola makan disajikan pada Tabel 17.

Tabel 17 Sebaran anak berdasarkan kategori pola makan

\begin{tabular}{clcc}
\hline No & Kategori & Jumlah & Persentase (\%) \\
\hline 1. & Rendah & 13 & 13,4 \\
2. & Sedang & 80 & 82,5 \\
3. & Tinggi & 4 & 4,1 \\
\hline Total & 97 & 100,0 \\
Nilai Minimal-Maksimal & \multicolumn{2}{c}{$55,00-84,16$} \\
Nilai Rata - Rata \pm Standar Deviasi & \multicolumn{2}{c}{$67,33 \pm 6,69$} \\
\hline
\end{tabular}

Tabel 17 menunjukkan bahwa sebagian besar pola makan siswa berada pada kategori sedang yaitu berjumlah $(82,5 \%)$, pola makan yang berada pada kategori rendah dan sedang termasuk pola makan belum optimal. Hal ini dibuktikan kurang terstrukturnya jadwal makan anak, orang tua memberikan kebebasan kepada anak dalam mengkonsumsi makanan favorit anak, orang tua selalu memberikan reward berupa makanan kepada anak agar anak dapat makan. Dalam hal ini orang tua memiliki peran penting untuk memberikan pengawasan kepada anak terkait pola makan, agar anak dapat mengkonsumsi makanan pokok sesuai dengan kebutuhan asupan gizi dan kalori tubuh sehari-hari untuk mengoptimalkan pertumbuhan dan perkembangan anak (Hayatus, Herman, \& Sastri, 2014).

Arifin (2015) mengatakan bahwa pola makan yang seimbang yaitu yang sesuai dengan kebutuhan disertai pemilihan bahan makanan yang tepat dapat meningkatkan status gizi baik. Pembahasan pola makan meliputi frekuensi makan perhari berkaitan pengaturan jadwal makan yang diberlakukan oleh orang tua kepada anak, untuk dapat meningkatkan pertumbuhan dan perkembangan fisik anak baiknya orang tua menerapkan pola makan yang seimbang yaitu menerapkan jadwal makan dengan frekuensi makan 3 kali sehari atau lebih, konsumsi makanan selingan diantara makan, jumlahnya disesuaikan dengan usia anak serta jenis makanannya bervariasi sesuai dengan gizi seimbang. Berkaitan dengan orang tua yang membebaskan anak untuk mengkonsumsi camilan, makanan favorit seperti minuman bersoda, junk food, dan makanan manis. Pada dasarnya anak usia sekolah gemar mengkonsumsi makanan manis. Namun, makanan manis memiliki risiko terjadinya obesitas, karies gigi dan gigi berlubang (Iklima, 2017), menyikapi situasi tersebut baiknya orang tua tetap memberikan pengawasan terkait dengan camilan dan jajanan yang dikonsumsi anak dengan memperhatikan kualitas makanan dan zat gizi yang terkandung dalam makanan.

Apabila anak ingin mengkonsumsi makanan manis, junk food dan minuman bersoda baiknya orang tua memperhatikan anak terkait intensitas konsumsi makanan dan minuman tersebut. Berkaitan dengan seringkali orang tua memberikan reward berupa makanan ataupun barang kepada anak ketika sulit makanan, berperilaku baik dan munculnya emosi negatif pada 
anak, orang tua dapat bertindak bijak dengan membatasi pemberian reward. Ketika anak merasa kesal, makanan ataupun barang bukan solusi yang dapat meredakan emosi negatif anak. Memberikan reward kepada anak atas perilaku yang baik memang dapat memberikan motivasi positif. Pemberian reward harus dipertimbangkan berdasarkan intensitas pemberian dan bentuk reward tersebut. Pada dasarnya reward yang diberikan atas perilaku baik bukan hanya berupa barang atau makanan melainkan kalimat-kalimat pujian dan kasih sayang juga termasuk reward yang memberikan motivasi positif bagi anak.

Dalam pengaturan pola makan, Pedoman Umum Gizi Seimbang menurut (Kemenkes RI, 2019) diantaranya ialah 1) Membiasakan konsumsi aneka ragam makanan pokok. 2) Membatasi konsumsi panganan manis, asin dan berlemak 3) Melakukan aktivitas fisik yang cukup dan pertahankan berat badan ideal. 4) Membiasakan konsumsi lauk pauk yang mengandung protein tinggi. 5) Cuci tangan pakai sabun dengan air mengalir. 6) Membiasakan sarapan pagi. 7) Membiasakan minum air putih yang cukup dan aman. 8) Perbanyak konsumsi buah dan sayur. 9) Membiasakan membaca label pada kemasan pangan. 10) Mensyukuri dan nikmati aneka ragam makanan.

\section{SIMPULAN DAN SARAN}

Sebagian besar anak usia sekolah memiliki pola makan belum optimal. Oleh karena itu, orang tua dan guru harus meningkatkan perhatian pada pola makan anak. Orang tua dapat memberikan aksesibilitas dan mengimplementasikan pola makan dengan pemilihan makanan yang sehat sesuai dengan menu gizi seimbang, orang tua dapat mengedukasi anak terkait pola makan yang baik untuk meningkatkan kemandirian anak dalam merencanakan pemenuhan makanan sehat, memberikan dukungan positif kepada anak untuk melakukan pola makan yang baik sesuai dengan disiplin jadwal makan, etika makan, dan menyediakan makanan yang bervariasi (karbohidrat, protein, lemak serta vitamin) demi terpenuhinya asupan gizi anak. Guru sebagai pihak sekolah disarankan untuk mengaktifkan pemantauan pola makan anak melalui pemasangan poster mengenai pola makan sehat, pertumbuhan dan perkembangan anak usia sekolah, dan memonitoring makanan-minuman yang di kantin.

\section{DAFTAR PUSTAKA}

Amourisva, S. A. (2015). Kontradiksi Kebiasaan Jajan Pada Anak Usia Sekolah Dasar. Jurnal Majority, 4(2), 143-146.

Anggraini, I. R. (2014). Perilaku Makan Orang Tua dengan Kejadian Picky Eater pada Anak Usia Toddler. Jurnal Keperawatan, 5(2), 154-162.

Anzarkusuma, I. S., Mulyani, E. Y., \& Jus'at, I. (2014). Status Gizi Berdasarkan Pola Makan Anak Sekolah Dasar di Kecamatan Rajeg Tangerang. Indonesian Journal of Human Nutrition, 1(2), 135-148.

Arifin, Z. (2015). Gambaran Pola Makan Anak Usia 3-5 Tahun dengan Gizi Kurang di Pondok Bersalin Tri Sakti Balong Tani Kecamatan Jabon-Sidoarjo. Jurnal Midwiferia, 1(1), 17-29.

Arsyad, F. W., Wahyuni, S., \& Ipa, A. (2013). Kejadian Tonsilitis pada Anak Usia Sekolah Dasar di Wilayah Kerja Puskesmas Minasatene Kab.Pangkep. Jurnal Stikes Hasanudin, 2(1), 1-7.

Elisa, A. (2012). Determinan Status Gizi Pada Siswa Sekolah Dasar. Jurnal Kesehatan Masyarakat, 7(2), 122-126.

Hamida, K. (2012). Efektivitas Penyuluhan Gizi dengan Media Komik untuk Meningkatkan Pengetahuan Tentang Keamanan Makanan Jajanan Sekolah Siswa Sekolah Dasar. Jurnal Kesehatan Masyarakat, 8(1), 69-76. 
Hayatus, R., Herman, R. B., \& Sastri, S. (2014). Artikel Penelitian Hubungan Status Gizi dengan Prestasi Belajar Siswa Sekolah Dasar Negeri 01 Guguk Malintang Kota Padangpanjang. Junal Kesehatan Andalas, 3(3), 460-465.

Iklima, N. (2017). Gambaran Pemilihan Makanan Jajanan Pada Anak Usia Sekolah Dasar. Jurnal Keperawatan BSI, 5(1), 8-17.

Jansen, E., Mallan, K. M., Nicholson, J. M., \& Daniels, L. A. (2014). The Feeding Practices and Structure Questionnaire: Construction and Initial Validation in A Sample of Australian FirstTime Mothers and Their 2-Year Olds. International Journal of Behavioral Nutrition and Physical Activity, 11(1), 1-13. https://doi.org/10.1186/1479-5868-11-72

Kustriyani, M., Widyaningsih, T. S., \& Prasertyo, A. (2017). Hubungan Peer Group Support dengan Perilaku Memilih Jajanan Sehat pada Anak Usia Sekolah di Madrasah Ibtidaiyah (MI) Al-Mukmin Prawoto Kota Pati. Jurnal Unimus, 1(1), 334-342.

Luh, N., \& Purnama, A. (2015). Jurnal Gizi Klinik Indonesia Perilaku Orang Tua dalam Pemberian Makan dan Status Gizi Anak Usia 2-5 Tahun. Jurnal Gizi Klinik Indonesia, 11(03), 97-104.

Ningsih, Y. A., Restuastuti, T., \& Suyanto. (2016). Gambaran Status Gizi pada Siswa Sekolah Dasar Kecamatan Rangsang Kabupaten Kepulauan Meranti. JOM FK, 3(2), 1-12.

Noviani, K., Afifah, E., \& Astiti, D. (2016). Kebiasaan Jajan dan Pola Makan serta Hubungannya dengan Status Gizi Anak Usia Sekolah di SD Sonosewu Bantul Yogyakarta. Jurnal Gizi Dan Dietetik Indonesia, 4(2), 97-104. https://doi.org/http://dx.doi.org/10.21927/ijnd

Nuzrina, R., Melani, V., \& Ronitawati, P. (2016). Penilaian Status Gizi Anak Sekolah Dasar Duri Kepa 11 Menggunakan Indeks Tinggi Badan Menurut Umur dan Indeks Massa Tubuh Menurut Umur. Jurnal Abdimas, 3(1), 62-67.

Octaviani, P., Izhar, M. D., \& Amir, A. (2018). Hubungan Pola Makan dan Aktivitas Fisik dengan Status Gizi Pada Anak Sekolah Dasar di SD Negeri 47 / IV Kota Jambi. Jurnal Kesehatan Jambi, 2(2), 56-66. https://doi.org/https://doi.org/10.22437/jkmj.v2i2.6554

Kemenkes RI. (2017). Hasil Pemantauan Status Gizi. Direktorat Jenderal Bina Kesehatan Masyarakat Direktorat Gizi Masyarakat.

. (2019). Pedoman Umum Gizi Seimbang. Jakarta: Direktorat Jenderal Bina Kesehatan Masyarakat Direktorat Gizi Masyarakat.

Widyantari, N. M. A., Nuryanto, I. K., \& Dewi, K. A. P. (2018). Hubungan Aktivitas Fisik, Pola Makan, dan Pendapatan Keluarga dengan Kejadian Obesitas Pada Anak Sekolah Dasar. Jurnal Riset Kesehatan Nasional, 2(2), 214. https://doi.org/10.37294/jrkn.v2i2.121

Yulia, C., Khomsan, A., Sukandar, D., \& Riyadi, H. (2018). Gambaran Perilaku Gizi Anak Usia Sekolah Dasar di Kota Bandung. Jurnal Media Pendidikan, Gizi Dan Kuliner, 7(1), 9-17.

Yurni, A. F., \& Sinaga, T. (2018). Pengaruh Pendidikan Gizi terhadap Pengetahuan dan Praktik Membawa Bekal Menu Seimbang Anak Sekolah Dasar. Jurnal Media Gizi Indonesia, 12(2), 183-190. 